\title{
Discussion on the Adjustment of Supervision Investigation Measures System
}

\author{
Zebing Lv \\ Law School \\ Sichuan University \\ Chengdu, China
}

\begin{abstract}
The current supervisory legislation cannot avoid the mixed use of investigation measures in duty violations, serious duty violations and duty crimes. Therefore, in the future, there is an urgent need to add additional compulsory attendance and awaiting trial measures, and it is necessary to sort out and rearrange the supervision investigation measures system. Specifically, it is necessary to set up a duty crime investigation agency and reduce the filing standards for duty crimes, and abolish the provisions of the "serious duty violations" standard. At the same time, the current local "review investigation room or discipline inspection supervision office" should be retained, being responsible for disciplinary review and duty violation supervision investigation.
\end{abstract}

Keywords-supervision investigation measures; compulsory attendance measures; mandatory awaiting trial measures; case filing

\section{INTRODUCTION}

Since the reform of the supervision system, relevant research has focused on the nature of supervision power, the relationship between the supervision lien and investigation power, and the connection between lien and criminal coercive measures. However, regardless of the views of various factions, the purpose of reform is still to crack down on duty crimes. Therefore, from the perspective of prosecuting crimes, whether it is investigative power or investigative power, it is completely possible to avoid falling into unnecessary noun arguments and unifying them in the scope of prosecution rights. The core of the exercise of prosecution right lies in the preservation and collection of evidence, the most important of which is the measures to limit the personal freedom of criminal suspects. Furthermore, from the perspective of the validity of prosecuting crimes, the current "Supervision Law" on the investigation of restrictions on personal freedom is only one type of detention. Therefore, comparing the provisions of the "Criminal Procedure Law" on compulsory measures, it can be found that the surveillance investigation measures lack such similar measures of summoning and detention. Moreover, there is a lack of supporting measures such as waiting for bail pending trial and monitoring residence. For this reason, according to the current supervision legislation, if the supervisory authority wants to interrogate the criminal suspect, there are actually no corresponding compulsory attendance measures. In the same way, before the transfer of the prosecution, in the face of conditions of detention, such as pregnancy, major illnesses, etc., the supervisory authority can only choose between lien and no lien. Therefore, as mentioned above, due to the lack of supervision investigation measures and the lack of supporting mechanisms for the retention measures, the future supervision law will require the addition of compulsory attendance measures such as summoning and detention, as well as compulsory attendance measures such as detention, bail pending trial, and surveillance of residence.

Logically, the status of the above measures in the existing system of supervision investigation measures has become a problem that must be faced directly. The above measures can be used for criminal investigation in the "Criminal Procedure Law". In principle, the additional measures should also be used only for duty crime investigations. However, the above-mentioned measures are also applicable to the serious duty violations provided by the "Supervision Law". The above-mentioned measures are more compulsory than those left in custody, and the weightlifting measures are light and light. The additional measures should also be applied to the investigation of serious duty violations.

However, the above logic is actually based on the premise that the operation of the monitoring procedure is strictly different between the investigation of the duties of the law, the serious duty violations and the crimes of duty crimes. Only on this basis can it be ensured that the additional compulsory measures are only applicable to serious duty violations and duty crimes. Specifically, once the above-mentioned types of investigations are mixed in the use of specific investigation measures, the newly added compulsory measures will also be abused. As the so-called the more increase in complexity, the more urgent the invasion. It is rather damaging on the protection of the human rights of citizens. Then, under the current legislative framework of supervision law, can the investigation of job violations, serious job violations and job crime cases be strictly distinguished? How should the system of additional investigation measures be adjusted? The following is the discussion of this issue. 
investigating them as serious duty violations when investigating cases of common duty violations with low social harm. In a nutshell, the current monitoring legislation on the investigation measures system and the case filing model actually weakens the applicable barriers between investigations.

It can be seen from the above analysis that in terms of the existing provisions of the "Supervision Law", it is impossible to avoid the mixing of various investigation measures among the above categories. Therefore, it is necessary to sort out and rearrange investigation measures system, whether it is from the current situation of the investigation measures system or from the compulsory attendance and awaiting trial measures that need to be added in the future.

\section{SPECIFIC ARRANGEMENTS FOR SUPERVISION INVESTIGATION MEASURES SYSTEM}

The arrangement of the investigation measures system should focus on the "serious duty violations" standard, and should also discuss how to issue disciplinary review and how to file a case for duty violations.

The first is the problem of setting the standard of "serious duty violations". As mentioned above, "serious duty violations", as one of the applicable standards for monitoring investigation measures, will most likely lead to the mixing of various investigation measures among standards due to the ambiguity of their regulations. Therefore, there are two kinds of solutions that can be foreseen: the first is to abolish the provisions on "serious duty violations" in the "Supervision Law", and reorganize the applicable relationship of various investigation measures with the dual standards of duty violations and duty crimes; the second is to refine the "serious duty violations" to strengthen the applicable barriers to investigation measures between standards.

The author believes that the choice of the two schemes should be based on the following two aspects: First, from the perspective of legislative technology, whether it is from the relationship between the wording of the articles and the content of the articles that have been analyzed in the previous article, or from the omission of the compulsory attentance and the provisions for awaiting trail measures, it is not enough to solve the problem. Therefore, the maintenance of law and stability is of course important, but the supervision law, as the basic law for the operation of the monitoring procedures, involves both the realization of the national anti-corruption policy and the protection of the basic human rights of citizens. It is necessary to strengthen the foundation and cultivate the base and then to modify and perfect. While the judicial interpretation can further stipulate relevant issues, but because it must be carried out under the current legislative framework, in the current rough legislative provisions, the effect is actually quite limited; Second, from the perspective of legislative purposes, the setting of the "serious duty violations" standard is mainly based on the fact that "corruption cases are highly secretive, and bribery cases are more well-known 'four-knows' cases - God knows, earth knows, you know, and I know. Lack of sufficient information and intelligence and special investigative 
techniques make it highly dependent on confessions for cases of corruption, especially bribery cases." 2 The legislation gives the supervisory authority the use of measures such as attachment, arrest, freezing, and detention to restrict the personal and property rights of the respondent during the illegal period of the job. The purpose is to strengthen the ability of the supervisory authority to collect and preserve evidence. It is precisely because of this consideration that some scholars believe that the exclusion of "serious duty violations" from the scope of retention,..., may lead to some of the results of the reform of the national supervisory system." ${ }^{3}$ However, the relationship between the abolition of the "serious duty violations" standard and the supervisory authority's discovery of duty crime is not a "zero-sum game" relationship. The latter can still be combined with the characteristics of duty crimes, and it can be guaranteed by adjusting the standards for the filing of duty crimes.

In summary, the author believes that an ineffectual remedy is not as good as taking a drastic measure to deal with a situation. It is advisable to choose the first option, abolish the standard of "serious duty violations" and adjust the case filing standards for duty crimes.

Specifically, in view of the various investigation measures that can be applied to the current serious duty violations. First of all, investigation measures restricting personal freedom such as compulsory attendance and awaiting trials are reserved for duty crime cases. In principle, non-registration shall not apply. At the same time, other investigation measures are reserved for the initial nuclear phase before the filing of the case - that is, for the investigation of duty violations. Therefore, it is possible to take into account the realization of crimes by the supervisory organs, help to absorb the more mature investigation measures legislation stipulated in the "Criminal Procedure Law", and maximize the guarantee of the connection between the inspection investigation procedure and the prosecutorial examination and prosecution procedures.

What needs to be specially stated is that the reason why the inquiries and freezes are downgraded to the criminal investigation before the criminal case is investigated mainly includes three points: First, the promotion of measures such as lien and other restrictions on personal freedom will adversely affect the ability of the supervisory authority to investigate evidence. Therefore, in addition to the reduction of criminal filing standards, it is also necessary to downgrade the investigation and freezing of the measures applicable to serious job violations to the investigation of ordinary duty violations so that it can reach a balance. Second, whether it is the "Administrative Supervision Law" that has expired, or

The grasp of this issue can refer to the current situation of the conflation between public security administrative power and investigative power appearing in the exercise of the powers of public security organs in China. Jiang Yong, Chen Gang, Research on the Misplacement of Public Security Administrative Power and Investigation Power - Based on the Perspective of Police Power Control [M]. Science of Law: Northwest University of Political \& Law, 2014, vol.06.

Zhang Jianwei, New Monitoring System from the Perspective of Legal Due Process [M]. Global Law Review, 2017, vol.02. the "Working Rules for the Supervision and Discipline of the Communist Party of China's Discipline Inspection Organs (Trial)", which is the basis for discipline inspection, there are all provisions for inquiring and freezing powers. Due to the discipline inspection and supervision working together, and illegal and disciplinary cases have a large possibility of overlap, even if the freezing measures are upgraded, the investigators will apply the freezing measures on the grounds of disciplinary investigation.

The second is the criteria for filing a duty crime investigation. The first paragraph of Article 39 of the "Supervision Law" stipulates that after preliminary verification, it is necessary to investigate legal responsibility for the suspected crimes committed by the supervisory object, and the supervisory authorities shall go through the formalities for filing the case in accordance with the prescribed powers and procedures. If the article 39 is horizontally compared with the provisions of Article 110 of the "Criminal Procedure Law" regarding criminal filing, it can be found that both have the same responsibility elements. However, Article 110 of the "Criminal Procedure Law" stipulates the factual elements as "having a criminal fact", while Article 39 of the "Supervision Law" requires "suspected criminal offences". In this regard, the "Interpretation of the Supervision Law" interprets the factual elements of Article 39 as "the fact that there is a duty violation or a duty crime". Although the "Interpretation of the Supervision Law" specifically states that the fact "only refers to the fact that some of the preliminary duties are illegal or duty crimes, not the facts of all duties or duty crimes", considering the facts referred to in the criminal case, it does not refer to all the facts of the crime. Therefore, it can be determined that the provisions for supervision and case filing are actually the same as the filing standards of Article 110 of the "Criminal Procedure Law".

In fact, the academic circles have always been quite arguable about the case filing standards stipulated in Article 110 of the "Criminal Procedure Law". The main reason is that the standard of filing is relatively high, which has caused the nihilism of the case filing procedure, appearing the anomalous phenomenon of "investigating without filing", "no detection no filing" and "filing after detection". It even provides an excuse for the investigation agency to waive the responsibility for prosecution or judicial corruption, emerging the situation that filing the wrong cases. Among them, the chaos of the preliminary investigation procedure is criticized by the academic circles, and even there is the radical viewpoint of abolishing the preliminary investigation procedure. ${ }^{4}$ Based on this, the call for lowering the criminal filing standards has always existed, and when such high filing standards reflected in the investigation of duty crimes, the above problems will inevitably show up. Therefore, the

Although this view is based on the "lien" measure, it is sufficient to prove that the concern about whether the abolition of "serious duty violations" will affect the investigation of duty crimes is indeed objective. Liu Yanhong, The Necessary Condition of Procedural Natural Law as Selfconsistency of Rules - The Legalization Path of "Supervisory Law" Lien Operation [M]. Journal of the East China University of Politics \& Law, 2018, vol.03. 
author believes that since the placement of lien, compulsory attendance and mandatory awaiting trial is not conducive to the discovery of duty crimes, it is necessary to lower the standard of filing to supplement the shortcomings.

The specific setting is to add a separate clause in the "Supervision Law", refer to the provisions of Article 107 of the "Criminal Procedure Law", abolish the expression "need to be investigated for criminal responsibility", and concretize "suspected crime" into "discovering criminal facts or criminal suspects". The complete statement is: After preliminary verification, the supervisory authority shall discover the facts of the crime or the suspect, and shall investigate and file the case according to the jurisdiction. In addition, it should also refer to the "Legislative Provisions of the Supreme People's Procuratorate on the Standards for Filing Cases of Infringement Cases" and the "Provisions of the Supreme People's Procuratorate on the Standards for Filing Bribery". Combined with practical experience and different characteristics of various types of duty crimes, the specific filing standards for duty crime cases shall be detailed. In the setting up of the internal organization, it is recommended to set up a duty crime investigation department, and the transfer personnel of the original prosecution authority will host the position.

The second is the issues of disciplinary review and the filing of duties violations. Despite that about the disciplinary inspection and the supervision investigation, one of them is the party discipline and the other is the national law, the differences in their application basis determine that the two should be treated differently in principle in the specific investigation, but in fact the two are difficult to distinguish. The reason is: first, from the perspective of supervising individuals, the disciplinary committee and the supervisory committee are highly integrated in terms of personnel composition. This point can also be seen from the setting up of the internal organs of the "review investigation room or discipline inspection supervision office". The insiders of the above-mentioned internal organization include both the personnel transferred from the procuratorial organs and the staff of the original discipline inspection and supervision authorities. Second, from the type of investigation cases, violations of discipline and illegal cases are often investigated simultaneously, which also makes the investigation measures of the two cannot and does not need to be applied separately. For example, Article 25 of the "Supervision Law" stipulates measures for attachment and detention. Article 28 of the "Working Rules for the Supervision and Discipline of the Communist Party of China's Discipline Inspection Organs (Trial)" also stipulates that the review team has the power to temporarily detain, seal, and freeze the money and materials involved. Due to the possibility of a large overlap between illegal and disciplinary cases, in the case that the same set of people violates the law and handles illegal cases, it is in fact impossible to distinguish whether the compulsory investigation of the property of the respondent is in the disciplinary inspection process or the inspection investigation procedure.
Therefore, since both the discipline review and the duty violation cannot be separated in terms of staffing or program operation, there is no need to make a specific distinction in the application of investigation measures. In the setting of the internal organization, the "review investigation room or discipline inspection supervision office" of the current localities shall be retained, and the overall investigation shall be conducted for the disciplinary review and the duty violation supervision investigation.

\section{CONCLUSION}

The legislative process of China's "Supervision Law" is relatively rushed. The design of the compulsory measures system cannot actually meet the needs of job violations and criminal investigations. Therefore, in the future, compulsory attendance and mandatory awaiting trail measures will be inevitably added. Moreover, there are certain problems in distinguishing investigation measures by the threedimensional standard of duty violation, serious duty violation and duty crime. Only in this case, the standard of serious duty violations should be abolished, and the filing standards for duty crimes should be revised. In the future, it should be noted that the investigation and measurement system of the "Supervision Law" should absorb the useful reference in the criminal lawsuit to the maximum extent, and the pursuit of duty crime should be incorporated into the rule of law that has been established in China as much as possible.

\section{REFERENCES}

[1] Yao Shijing, Yu Baohua, "Right" and "Wrong" in Criminal Case Filing [M]. Journal of the East China University of Politics \& Law, 2008, vol.05. (in Chinese)

[2] Wang Lifeng, Lv Yongxiang, The Theoretical Connotation, Practical Significance and Optimization Path of the Joint Work of the Commission for Discipline Inspection and the Commission [M]. Henan Social Sciences, 2017, vol.11. (in Chinese)

[3] Jiang Yong, Chen Gang, Research on the Misplacement of Public Security Administrative Power and Investigation Power — Based on the Perspective of Police Power Control [M]. Science of Law: Northwest University of Political \& Law, 2014, vol.06. (in Chinese)

[4] Zhang Jianwei, New Monitoring System from the Perspective of Legal Due Process [M]. Global Law Review, 2017, vol.02. (in Chinese)

[5] Liu Yanhong, The Necessary Condition of Procedural Natural Law as Self-consistency of Rules - The Legalization Path of "Supervisory Law" Lien Operation [M]. Journal of the East China University of Politics \& Law, 2018, vol.03. (in Chinese) 